\title{
Pragmatism, moral responsibility or policy change: the Syrian refugee crisis and selective humanitarianism in the Turkish refugee regime
}

\author{
Umut Korkut
}

Correspondence:

Umut.korkut@gcu.ac.uk

Glasgow Caledonian University, Glasgow School for Business and Society, Cowcaddens Road, G4 OBA Glasgow, UK

\section{Springer}

\section{Introduction}

This article scrutinizes how the Syrian crisis affects the management of Turkey's refugee regime. It also analyses how the Turkish government has treated the Syrian refugees preferentially in comparison to refugees of other nationalities. The article illustrates that the current Turkish humanitarian assistance to refugees is selective, and it predominantly welcomes those that have religiously, ethnically and politically acceptable backgrounds to the Islamist AKP (Justice and Development Party) ideology in government. This attitude is merely in line with the selective application of what remains as the anomaly of the Turkish asylum regime, that is, it limits itself to accepting asylum applications only from European nationals. This geographical limitation dates from the time when Turkey adopted the 1951 Geneva Convention on the Status of Refugees in 1961, while having published a declaration that it would admit only aliens coming from Europe due to the geographical region in which Turkey is located. NonEuropean asylum seekers who qualify for the internationally accepted 'refugee' definition are granted the right of temporary asylum (Asylum and Migration Legislation, 2005, pp. 13-14) in Turkey, while the UNHCR deals with their cases to find a country of settlement. This process can take years in many instances, and these refugees can neither leave their places of temporary residence nor be afforded any employment rights while waiting.

Similar to the AKP, based on their ideologies, previous governments have also been lenient toward non-European refugee groups despite the geographical limitation policy. In addition to accepting Bosnians, Bulgarian Turks, and Kosovars, thereby, previous right-wing governments settled Afghans of Turkic descent in Eastern Turkey in the 1980s, and later allowed immigration of Ahiska Turks from Central Asia in the 1990s as 'national refugees' (Baydar Aydıngün, 1998-1999). Looking at the Syrian case, this article argues that the AKP's humanitarianism in Turkey is merely a continuation of the selectiveness that these governments also pursued. Yet, the numbers are incomparably higher this time, raising doubts about how the AKP government can retain its pragmatic stance with selective opening.

The empirical context that informs this article is the Syrian refugee population of more that two million in Turkey, and their status under two new laws that deal with

(c) 2016 Korkut. Open Access This article is distributed under the terms of the Creative Commons Attribution 4.0 International License (http://creativecommons.org/licenses/by/4.0/), which permits unrestricted use, distribution, and reproduction in any medium, provided you give appropriate credit to the original author(s) and the source, provide a link to the Creative Commons license, and indicate if changes were made. 
them and stateless people coming from Syria within a 'temporary protection' framework (Göç İdaresi Genel Müdürlüğü n.d.). In effect, this status allows Syrians to receive protection in Turkey. However, as an impact of, first, the discursive making of the Syrian crisis by the AKP government as a war between the Sunnite victim and Alawite oppressor and, second, Turkey's association with the Sunnite warring factions in Syria, the ethnic and religious background of Syrian nationals, there is a difference in terms of what Turkey offers in practice and what the refugees are willing to accept.

Nevertheless, the principles of temporary protection are such that Turkey will maintain an open border policy' for all Syrians, and it will respect their non-refoulement on condition that they register with the Turkish authorities. The policy includes renewable but unlimited stay, protection against forcible returns, and access to reception arrangements where immediate needs are addressed. Yet, temporary protection precludes any right for permanent residence and, ultimately, citizenship. Therefore, while the state has been willing to extend some security and protection to Syrians, it is still reticent to guarantee their permanence in and integration with Turkish society. In practice, temporary protection means the provision of services to those in camps, but a lack of similar protection to those outside the camps. At the time of writing (early summer 2015), assistance to non-camp refugees has been ad hoc and delegated to local actors such as NGOS or local governments, with the notable exception of the state guaranteeing their continuous access to public medical healthcare. Outside the camps, Syrians of school age with residence permits can enrol in public schools or attend informal schools taught in Arabic and run by volunteer Syrian teachers and supported by local authorities or NGOs (UNHCR, n.d.). However, given their swelling numbers, finding teaching facilities has been problematic. Regarding access to employment, at the time of the interviews in winter 2014, the Turkish Ministry of Labour indicated that, with temporary protection, there also came renewable one-year work permits. ${ }^{1}$ However, there is as yet no systematic analysis of the Syrians' uptake of work permits.

This article argues that, despite resting on a legal framework, the temporaryprotection framework is an essentially discursively constructed mechanism with vague implications, particularly regarding settlement and integration. To give a few examples, there is a selective operationalization of temporary protection following the AKP government's discursive construction of the typical Syrian refugee as a Sunnite victim escaping the atrocities of the Alawite Assad dictatorship. The management of services provided to Syrians is delegated to AFAD (Disaster and Emergency Management Presidency), indicating that the government assesses Syrians in Turkey within a crisis management framework. The Law includes a clause that temporary protection should not imply any threats to national security. Upon complaints from the locals, Syrians have been transported out of Turkish cities either to camps or to other cities. The political authorities, including the President, have been keen to emphasise publicly that Syrians will go back to their countries once the Assad regime is ousted.

Therefore, in order to analyse how the AKP government has framed the Syrian refugee crisis in Turkey, this article introduces discursive governance as a theoretical tool. Discursive governance works more efficiently to address the 'selective opening' and 'preferential treatment' narratives of AKP, rather than the formally institutionalized immigration systems in which the rights of refugees and protection by the host state and nation toward the refugees are much clearer. When investigating how political 
narratives affect the governance of the refugee crisis, therefore, discursive governance helps us to understand the process in which political discourses become normative mechanisms: first, by marking socially constructed realities in politics; second, by playing a role in delineating the subsequent policy frames; and third, by influencing the public sphere (Korkut, Mahendran, Bucken-Knapp, \& Cox, 2015). In this context, discursive governance has operated in the following manner. Since its initiation, the AKP has delineated the Syrian refugees as merely Sunnite Muslims and in so doing politically engaged with the Syrian crisis as an active supporter of the Sunnite forces in Syrian opposition (Aras, 2004; Gürsel, 2012; Han, 2013; Hinnebusch \& Tür, 2013). This deliberate narration of the crisis as a war between the Sunnite victim and Alawite oppressor sought to justify preferential treatment for Syrian refugees as the rightful recipients. It was also aimed at preventing a possible reaction from the public, which is generally nativist and essentially foreignness-averse (Korkut, 2014) regarding the refugees. That is why the temporary-protection legislation introduced in 2014 extended protection merely to Syrians but not to other refugee groups in Turkey. Moreover, as an impact of Turkey's overt discursive, political and military association with the Sunnite forces to drum up support from the AKP constituency, non-Sunnite Syrian refugees have been reticent to fully take up the protection that the legislation has provided.

As I will spell out below, to gain support, the tenets of opening have appealed to the collective memory of the public as Turkey being a 'charitable' polity with close personal and historical relations with the Syrian nation. The discursive making of selective humanitarianism therefore reflected on 'how things have been and always are' in Turkey and within Turkish society. These discourses qualify 'innovative' policy-making at the central and local levels of public administration in response to the troubles of Turkey's Syrian 'guests' - according to Turkish public administrators interviewed for this article. Thereby, governance through discourses has enabled the government to avoid extending full protection to all refugee populations on Turkey's territory, and bolstered its role as a host to Sunnite Syrians. In the end, the AKP government merely maintained earlier political preferences of the Turkish state, and it accepted only those refugees that were religiously and sometimes ethnically in confluence with the composition of its voter base. However, Turkey has faced a more complex refugee problem since summer 2014 with the emergence of so-called the Islamic State (IS), as the Syrian civil war spilled into Iraq and engulfed the Kurdish areas in Syria bordering south-eastern Turkey. As I argue below, the complexity that the refugee crisis has gained presents us with a possibility for comparing the protection for Syrians with others in Turkey, but particularly the Middle Eastern refugees suffering from the regional repercussions of war in Syria.

In order to delineate the tenets of pragmatism, moral responsibility and selective opening, the article offers the following. The first section looks at the implications of the Syrian refugee crisis for Turkey, presenting the background to the crisis, the development of the guest narrative, and the troubles that mass reception of refugees has generated. In the second section, I propose why discursive governance offers the most optimal format for dealing with the Syrian refugee crisis rather than a formally institutionalized immigration system. This reflects on reactions to foreignness among the Turkish public as well as the recently changing ethnic and religious composition of refugees arriving due to the regional repercussions of civil war in Syria. The subsequent 
empirical discussion comprises two sections. First, I delineate selective opening and preferential treatment discourses that govern the Syrian refugee crisis by reflecting on interviews with Turkish bureaucracy. Second, I illustrate the implications of discursive governance for refugees by depicting a comparative picture of Syrians and others seeking protection in Turkey. In conclusion, I reflect on how the ideological tenets of selective opening and humanitarianism preclude more permanent integration policies that not only the refugees in Turkey but also Turkish society need to come to terms with as Turkey remains a target county for international migration flows.

\section{Syrian refugee crisis - a brief overview}

The Syrian crisis is an important case study for Turkish foreign policy in action. According to an interviewee at the Turkish UN Delegation in New York in 2014, its involvement in Syrian refugee protection made Turkey a 'proactive' state in contributing to refugee policies at the international level. In essence, taking the opposition side in the Syrian civil war against the Assad regime became a means for the AKP government to showcase its grand strategy and regional leadership ambitions in the Middle East. However, Öniş, (2014) identifies two important limitations of Turkey's policy towards Syria. They are, first, that Turkey's efforts to play a leading role in terms of instigating regime change in Syria failed, and, second, that Turkey has been drawn into sectarian conflicts as a consequence of its over-activism and over-involvement in Syrian domestic politics. Looking at the earlier official declarations, it may appear that the Turkish government almost welcomed Syrian refugees, hoping that this would enhance the international attention on the crisis in Syria. The then Prime Minister - now President - Recep Tayyip Erdoğan's statement in 2011 that 'Syria is Turkey's internal affair' illustrates that humanitarian and ethical considerations as well as realpolitik drove Turkey's Syria policy (AKP, 2011).

This article offers a third dimension to study Turkey's engagement with the Syrian crisis, bearing in mind the narrative of historical and moral responsibility that guides its policy actions, particularly with respect to Syrians. Prime Minister Davutoğlu (2013) 'humanitarian diplomacy' narrative underlines this dimension. According to Davutoğlu, this means that Turkey's influence is to be felt over a wide geographical area, not only symbolizing its power but also symbolizing its conscience. This influence

[i]s based on a critical equilibrium between conscience and power. In this equation, if a state has conscience but no power, it shows weakness. If it has power but no conscience, it becomes a tyranny. Our idea is for Turkey to be a compassionate and powerful state. One will be compassionate if one's conscience dictates where one should go and to whom one should reach, as can be seen from the examples of our aid to Somalia and Syrian refugees. At the same time, one will need to have power, so that one has the ability to reach where needed (Davutoğlu, 2013, p. 867).

The means of humanitarian diplomacy are to be Turkish Airlines, TIKA (Turkish International Cooperation and Coordination Agency), NGOs, Kızılay (Turkish Red Crescent), and TOKI (Housing Development Administration of Turkey), as well as the state apparatus acting in coordination as reflections of Turkey's power and ability to assist people (Davutoğlu, 2013). However, this humanitarian diplomacy has so far not 
implied that Turkey would assume responsibility for all refugees on its territory or remove the geographical boundary from its asylum law.

There have been previous studies (Castles, 2000; Teitelbaum, 1984; Zolberg, 1989 and Zolberg, Suhrke, Aguayo, 1986) that foregrounded Western states' - particularly the United States' - involvement with immigration and refugees as a foreign policy tool. However, their works did not use discursive theoretical tools and approached study of immigration within the realist framework. While this framework informs this study, I will elaborate on Turkish engagement with the Syrian refugees as a particular reflection of the new humanitarian diplomacy narrative of Turkish foreign policy.

The influx of refugees commenced with the crossing of about 250 Syrians into the Hatay province towards the end of April 2011. Following this instance, the then Turkish Foreign Minister Ahmet Davutoğlu announced that Turkey was ready to allow in those Syrians 'who are not happy at home', and this effectively unleashed the opendoor policy for Syrians initially escaping the clashes between the government and the opposition (Ilgit \& Davis, 2013) and latterly escaping the clashes between various militant groups. Despite the expressions of political support for the refugees, however, the Turkish state raised concerns. In March 2012, Erdoğan appealed to the UN to establish a 'safe haven' inside Syria for Syrians facing 'humanitarian disaster'. Turkey repeated its request in August as the number of refugees approached 100,000. It recalled Turkey's push for a safe haven in northern Iraq following the 1991 Gulf war, when 400,000 Iraqi Kurds had crossed the mountains into Turkey. Then, with US backing, the UN mounted Operation Provide Comfort to relocate the Kurds into a zone of northern Iraq and protect them there (Ilgit \& Davis, 2013). Thereafter, Turkey initiated a major humanitarian effort to accommodate the large numbers of refugees. By June 2013, about 580,000 Syrian refugees were accommodated in camps along the Syrian border (UNHCR, 2013). According to 2014 UNHCR figures, since the beginning of the civil war in Syria, Turkey has received around two million Syrian refugees. While almost a quarter of Syrians live in refugee camps, the rest have been dispersed all around Turkey, living in temporary accommodation and involved in informal employment.

The Syrian crisis triggered changes in the Turkish refugee regime in the form of developing 'temporary protection' for Syrians and the establishment of a new immigration agency in 2013 and 2014. This agency is intended to serve under the Ministry of Interior Affairs with offices in all the Turkish provinces. However, at the time of the interviews in 2014, it was still going through consolidation and was shadowed by AFAD (Disaster and Emergency Management Presidency), serving under the Prime Minister's Office in dealing with refugee issues. At the time of writing in summer 2015, this immigration agency did not appear central to any relief and integration efforts.

The temporary protection qualifies Syrians in Turkey not as refugees but - as it appears in various comments from officials - as 'guests'. As Özden's (2013) study showed, however, many Syrians in Turkey complained about not being granted refugee status, and that their 'guest' status implied unpredictability about their presence. Essentially, lacking refugee status is an important factor that increases the vulnerability of Syrians as informal labourers and as child labour, as a recent report from Izmir province showed (T24 2015a). Furthermore, a worker for one of the local authorities in Islahiye, quoting Özden (2013/05), stated that 'the guest status means that Syrians do not have rights in Turkey and that the state has the right to make the decision to deport them at 
any time'. Another official in Islahiye indicated, also quoting Özden (2013/05), that 'being a strong state means that you feel pity. The Turkish state feels pity towards Syrians and this is why we feed them and let them stay in Turkey'. In other words, temporary protection for Syrians essentially operates not based on formal rights, but rather on the discourse of generosity of Turkish public. At the same time, it indicates to the Turkish public that the Syrians in Turkey are a temporary presence. However, such a charitable approach rather than a rights-based approach feeds negative public opinion in Turkey towards refugees. Many have expressed their discontent with the Turkish government allocating resources to Syrians instead of Turkish citizens who are in need. Some of the words they use to define Syrians include 'beggars', 'looters' and 'exploiters' (Özden, 2013/5).

The inter-ethnic clashes, protests, and conflicts in the latter part of 2014 indicated that the general aversion to foreignness in Turkey (Korkut, 2014) was also directed at the Syrian refugees. Since then, the Turkish media has regularly reported problems and clashes between the Turks and the Syrian refugees from provinces not only in south-eastern Turkey, such as Gaziantep, Şanlıurfa or Kilis, but also Mersin, Adana and Kahramanmaraş, as well as various districts of Istanbul and Ankara. One of the most serious ones was in an industrial district of Istanbul in August 2014, where hundreds of protestors clashed with the police, chanting anti-Syrian slogans and attacking local Syrian businesses on the premise that two Syrians beat a Turkish child (BBC, 2014; Milliyet, 2014) reminding us of blood libels in Europe against the Jews in Middle Ages. News from the Turkish resort of Bodrum in May 2015 showed that the police sent Syrians to another town in inland Turkey when the owner of a famous bar complained that they were a disturbing sight for tourists (T24, 2015b).

After conflicts between protestors, such as business owners and youths, and the Syrians in other provinces, Turkish police generally removed the Arabic signs from Syrian businesses already crowding the commercial districts of Turkish towns along with the Syrian families from their inner city locations to camps. In responding to these clashes, the coordination meeting among state departments responsible for Syrian refugees on 23 August 2014 declared the following.

Turkey has presented an exemplar of coordinating the refugee crisis for the past three years and the Turkish nation deserves full esteem for hosting their brotherly guests from Syria. The Syrian guests, who are under temporary protection, have also been careful with conforming to and not distributing society. However, despite all the positive circumstances, agitation and disinformation instigate xenophobia.

After laying out the generosity of Turkey and temporariness of Syrians, the response of the Turkish government to conflicts with Syrians was the following.

There will be a precautionary reaction to begging, prostitution, and polygamy [allegedly on the rise since the Syrians' arrival in Turkey]. The state will strengthen its efforts to solve the complications in the labour market due to the increasing population of Syrians in Turkey. The state will take all measures against all economic activities that generate unfair competition and informal labour. The Syrian 
children will be put into school and will be encouraged to learn Turkish in order to prevent social problems (AFAD, 2014).

It is obvious that the presence of Syrians in Turkey is instigating a reaction from the local population, and the AKP government strives to guarantee precautionary solutions while emphasizing the temporariness of the situation. During the 2015 general election campaigns, the Syrian refugee issue became a point of debate with the main opposition CHP (Republican People's Party), arguing that they should be sent back home when their safety is guaranteed, whereas the Kurdish-dominated HDP (People's Democracy Party) was asking for citizenship rights to be extended to Syrians. After the June 2015 election, a new MP from Gaziantep province elected on a MHP (Nationalist Action Party) ticket claimed that his election showed that the voters disgruntled with Syrians were leaving the AKP. However, despite these conflicts and clashes, we cannot claim that the public aversion to Syrians had major political costs for the AKP thus far. To some extent, this may be due to the narrative of historical moral responsibility and temporariness that the officials have been so keen to emphasize, as I will spell out in the next section.

\section{The discursive making of selective humanitarianism}

The temporary-resident category, developed for Syrians, not only illustrates the operation of a pragmatic approach to humanitarian assistance, but also selectiveness. The category appeals to the collective memory of Turkish society and promotes Turkey as a charitable polity with a responsibility for people from its imperial past. The selective application of protection also shows that it is the innate characteristics of incomers that qualify them for the degree of reception and protection rather than a comprehensive humanitarian approach toward refugees in Turkey. Rather than formal institutionalization of humanitarianism, therefore, what we see is state authorities' narrative-setting to justify Turkey's temporary involvement and moral responsibility to Syrians.

Theoretically, this article explores how policy and politics create social knowledge, and make some ideas publicly salient (Cox \& Béland, 2013; Korkut et al. 2015; Searle, 2010). Discursive processes can enhance their resonance once they operate in conjunction with institutional mechanisms in political contexts, qualifying the subsequent social processes and power relations. Hence, talk in institutional settings can allude to the "interaction process in which what is "text" one moment becomes "con-text" the very next' (Fairhurst, 2009, p. 1611; Iszatt-White, 2011, p. 123). In this sense, narratives serve the dual purpose of providing an explanation of events while allowing individual interpretation (Bruner, 1996). It is through explanation that an individual develops an understanding of how the world is progressing and how he or she fits within the story of progression (Bruner, 1996; Patterson \& Monroe, 1998). Political authority can impart an impact on this process via setting rules that do not just regulate, but also create the possibility of the very behaviour that they regulate (Searle, 2010). Essentially, discursive governance refers to implicit mechanisms of governance resting on narratives, leitmotifs and strategic metaphors in political language, and the subsequent framing of policies using such language to interpose ideas in order to affect political and social representations within the public sphere in accordance with the wishes of political authorities (Korkut et al., 2015). 
The communicative function of narrative requires the narrative-setting authorities to persuade a broader audience of the legitimacy and appropriateness of their particular version of a situation. Narratives are not neutral representations of current conditions, but can serve to suggest an interpretation of what the state of the world ought to be. Then, discourse circumscribes the range of subjects and objects through which people experience the world, specifies the views that can be legitimately accepted as knowledge, and constitutes the actors taken to be agents of knowledge (Fischer \& Gottweis, 2013). In terms of persuading individuals and influencing their beliefs, research in psychology shows that narratives have a stronger ability than scientific evidence (Shanahan, McBeth \& Hathaway, 2011). The constitutive function of narratives includes not just naming the problem, but also scripting the identities and roles of the various actors involved in it. Narrative construction is an organic process, involving actors who initially gravitate in a particular direction because they perceive themselves to be affected by a situation (Bhatia \& Orsini 2014).

In order to depict and debate the development of narratives and thought patterns supporting a selective humanitarian approach, we can develop the following theoretical position. Ad hoc discourses qualifying the Syrians as guests and brothers circulated in the public sphere generate a space where politicians configure, transmit, and initiate politics ideationally, rather than vouchsafing substantial policy change in effect to governance towards a comprehensive policy change in the asylum regime. Hence, we have some refugees - temporarily - accessing protection in Turkey, while others remain insecure and devoid of rights even if they also suffer from comparable humanitarian crises. Thereby, the Syrian is marked as a 'guest' that needs protection, whereas the migrant remains a threat.

Hence, this discourse influences the public sphere in a way the public considers Syrians as temporary guests, while the government tries to stop the arrival of refugees. The ideational mechanisms, in this regard, are much more explicit than formal policy changes. Refugees do not have rights but temporary qualifications based on their innate characters. Reception and integration are not embedded in policy, but constructed selectively and discursively. Each person's understanding of narratives such as temporary guest, brotherly nation, moral responsibility, and religious advocacy is based on a combination of personal experience and culturally transmitted stories, images or frames (Gamson, 1992; Lakoff \& Johnson, 1980; Nimmo \& Combs, 1980), rather than the Turkish state formally adopting and extending humanitarian assistance regardless of innate characters of migrants. This way, hosting Syrians remains temporal, and incremental change remains devoid of political costs.

In order to reflect on these theoretical assumptions, I carried out interviews at three levels of Turkish public administration in 2014. The first one was the central level, that is, officials based in Ankara, where I held interviews at AFAD and the Ministry of Foreign Affairs. I also interviewed officials in the Ministry of Labour in a focus-group format, given that the Syrian refugees have engaged in both formal and informal labour. Moreover, in order to balance the reflections of public officials on the reception of Syrian refugees, I also interviewed officials at Turkish Red Crescent and the International Organization of Migration in Ankara. The second was the local level to appropriate the divergence between the central and local bureaucracies regarding the handling of Syrian refugees. In Gaziantep, I interviewed the regional Governor in 
charge of the Syrian refugee crisis and the AFAD chief, and in Kilis the Governor, given his position serving in a small border province facing swelling numbers of refugees. Gaziantep and Kilis are also the provinces where Turkish citizens have claims to 'family' links with Syrians across the border. Especially in Kilis, where the economy is mostly based on smuggling, kinship relations have remained strong over the years due to the economic relations over the border. The existence of relatives and business partners across the border on the Turkish side motivated many Syrians to flee to Kilis (Özden, 2013/5). Yet, these provinces also feel the impact of Syrian refugees on businesses, the labour market, and access to public services such as healthcare and education, as well as crowding out the housing market due to the increased population.

Finally, the third level was international, that is, the Turkish Delegation to the United Nations. The UN has become a crucial platform for Turkey to attract international support for its case in Syria and to showcase the 'humanitarian diplomacy' of Prime Minister Davutoğlu. The interview assisted me to delineate the Turkish position regarding the Syrian refugee crisis. Moreover, I examined the speeches of Davutoğlu delivered at the UN General Assembly on the theme of the Syrian crisis. In order to safeguard unanimity, I qualify these interviewees with the place and the date of interview but do not mention any names.

\section{Discursive making of Syrians as 'guests', refugee crisis as 'temporary', and Turkey's responsibility as 'historical'}

Given the central position that AFAD occupied in view of the refugee crisis, it appears that the Turkish government handles refugee relief operations within an institution that deals with disasters. Disasters are temporal in essence. Retaining the control of mass movement of people from Syria into Turkey in this institution helps authorities to convey to the public that the Syrians' presence in Turkey is temporary. However, the nature of the Syrian refugee crisis also presents the Turkish public administration with an unprecedented challenge. In order to assess their positions within this environment, I give a brief account of my interviews below and present how the emerging discourses feed into the 'selective humanitarianism' and 'pragmatism with geographical limitation' narratives.

Though not a refugee agency, AFAD has registered Syrians upon entering Turkey since the beginning of the crisis. As AFAD operates under the Prime Minister's Office, its active engagement illustrated the attempt to centralize the refugee crisis directly under the then Prime Minister Erdoğan. In this respect, insomuch as Erdoğan has actively engaged with the Syrian crisis, AFAD became the main hand of the central administration. In February 2014, at an interview in Ankara, an AFAD official qualified his role responding to the refugee crisis as follows: 'As the refugee crises tend to imply emergencies, the 2012 declaration [that appropriated AFAD as the main agency of coordination] restrained the legal obligations of other agencies [... while] AFAD determines the policy at the centre [...] but leaves its application to governorships [in provinces]. While we work under the office of Prime Minister, we are also above the provincial governors' (AFAD Ankara Interview, February 2014).

AFAD runs refugee camps in collaboration with the Turkish Red Crescent, registers Syrians and issues them with identity cards to provide them with access to services. If the governors in the provinces need staff in order to attend to the needs of refugees in 
camps, AFAD either provides them or organizes with other provincial governors to transfer personnel. AFAD is in charge of all expenses for relief operations. During an interview at the Gaziantep office of AFAD in May 2014, I witnessed that the AFAD official practically signed all requests for payment issued by the Governor's office to local hospitals and various businesses supplying daily amenities in relation to Syrians' expenses at the camps. When I asked him how long this could continue, he simply stated that it would continue until the state told the Syrians that it was time to leave.

Eventually, they are not our personal guests. They are the guests of the state. That is why we would not use any [personal] initiative when it comes to dealing with them. We act in co-ordination with Ankara. We have learnt by doing, and established an informal structure without formality (Gaziantep, AFAD, May 2014).

The interviewee also complained about the increasing rents in Gaziantep as a result of the influx of Syrian refugees.

When I inquired at AFAD in Ankara why they deal with Syrians, the interviewee indicated that they were experienced from the previous Bulgarian (1989) and Iraqi crises (during the Gulf Wars), and suggested that these experiences stimulated an 'initial brainstorm'. The interviewee's reflection on the crisis management framework was as follows:

Does this [AFAD's involvement] have any legal provision? AFAD considers migration as crisis and deals with it via humanitarian aid. [...] The open door policy is so extensive that you can bring it into political debate or [consider it within the frame of] humanitarian aid issues. You can even consider it as a military issue. Had it been a military crisis, this would have been delegated to security forces. However, as this is considered a humanitarian crisis since the first entry on 29 April 2011, AFAD became involved (Ankara, February 2014).

The mechanism of responding to the Syrian refugee crisis took the form of Syrian co-ordination meetings regularly held among all agencies involved [inter alia Directorate-General of Security; Department of Foreigners, Borders, and Asylum; Ministry of Education; Ministry of Health; Directorate-General of Religious Affairs; Governors] to offer 'practical' solutions (AFAD Interview, Ankara, February 2014). The institutional composition of co-ordination meetings changed in time as more agencies - such as the Ministry of Family and Social Policy and the Ministry of Education joined while 'temporary crisis' evolved into 'permanent crisis'. In this respect, the interviewee mentioned that health costs have become a major issue over time, such that 'if we cover all expenses of these [Syrians], this can turn into healthcare tourism while the open door policy is in order'.

My next query to AFAD related to the sustainability of current policy, given the unremitting nature of the influx of refugees. The AFAD interviewee in Ankara described how the government sustains its position vis-à-vis the Syrians in the public sphere as follows: 'The Turkish people in terms of assistance are strangely unique [...] and people support this assistance structure individually'. When I further inquired whether their institutional structure reflected Turkey's culture, the interviewee stated: 
We are a very practical country. In the West, for example, if there would be [a need for] humanitarian assistance for somewhere, believe me, it is very difficult. Turkey is very practical. It is so simple with us as [our advantage is we are] under the authority of the Prime Minister's office, perhaps thanks to our public administration structure, perhaps thanks to our social structure.

It is hard to miss the reference in these claims to a collective memory of 'how things have been and are' in Turkey and with Turkish society when it comes to dealing with crises. Framing Turkey's responses with these narratives helps to substantiate humanitarianism. However, this does not present any indication of an inclusive and institutionalized response that may provide relief to all refugees in the country. When reflecting on Syrians, references to collective memory were also apparent during interviews with other officials. As illustrated in the next section, these references to collective memory generate discursive tools to frame the Syrian refugees as 'guests' in the public sphere in comparison to the troubling essence of having refugees.

In response to the Syrian crisis, the Ministry of Foreign Affairs (MFA) coordinates Turkish humanitarian efforts with international agencies 'not within the political but the legal frame of the crisis' (MFA interview 1, Ankara, February 2014). The MFA personnel have been deployed at the regional level in order to engage with the visiting international delegates. Their role implies that 'they [operate] in the name of the international community; this is a problem of international community. When Turkey assumes responsibility, it is decreasing the extent of the burden [that the Syrian refugees pose] on the international community' (MFA interview 1, Ankara, February 2014). As depicted above, the responsibility for refugees, assumed in the name of the international community, resonates in Turkey's discourse at the UN level as well.

Along with the much-emphasized special nature of the Turkish people, ample economic means of the Turkish state and its pragmatism, interviewees at the MFA and the Ministry of Labour also pointed out Turkey's responsibility for Syrians, given its imperial past in the Middle East and the collective memory prevailing amongst the population about the generosity and charity of the Turkish polity. Whether this was successful or not was subjective, according to the interviewee at MFA.

We need to consider the reasons that form the basis of these assessments. Now, if we were going to ... I will relate this to migration ... in a country with which we have 900 kilometres of borders, and especially if this country is Syria. Well, if we consider the interrelationship between the Turkish and the Syrian populations perhaps for centuries, there can be no argument for closing the borders for Syrians (MFA interview 2, Ankara, February 2014).

The tone of debate at the Ministry of Labour in Ankara conveyed similar themes:

Now, if you consider our national values, cultural values, historical friendship, let's say brotherhood, the basic reason that we are assisting the Syrians at the moment starts from here and goes on up to politics at higher levels including the Prime Minister [then Erdoğan]. Now, we have these basic values. It is difficult to explain our alms-giving institution abroad. Everyone gives money to their poor without expecting anything in return. Isn't that so? Economically, in fact, this is not rational. 
Now, we did something under these circumstances and they came. This is our basic justification: people should not suffer (ML focus group interview, Ankara, February 2014).

The extension of temporary work permits to Syrians also implies practical advantages for Turkey's economy, as they engage in informal labour with payments lower than the minimum salary and lack of safety at work. Yet, the ML was oblivious to these issues and, when asked, reflected once more on the generosity and facilities of the Turkish polity.

[I]f the question is whether our labour market needs these people or not, well no. But occupation of these people is a type of social policy. Turkey has facilities. Well, when you look into our state traditions, from the beginning in situations as such the state has always striven to maintain its social state role and now it tries to do the same.

The interviews with local heads of bureaucracy in Gaziantep and Kilis presented a more realistic perspective of the implications of Turkey's engagement with Syrian refugees. Although references to the collective memory of Turkey's responsibility for its neighbour were still evident, doubts also emerged about Turkey's capabilities for continuous commitment to the crisis. The two governors interviewed in the region in May 2014 indicated insufficient financial and administrative capacities of their offices in terms of limited number of Arabic speakers and budgets at the time of the interviews. Hence, according to Governor 1:

We feel the crisis in Syria within ourselves, and the people over there are our relatives. And we will do as much as we can. However, despite this discourse, this is not how we are in the field. That is my real worry [...] Well, these are our religious brothers. [...] Now, those who do not suffer would not know the troubles of those that suffer, and the people over there have close kinship with Turkey. If this happens to you, where would you go? You go to where your closest relatives are. These are fallen [people]. Now, when we say this we can convince our people. However, if at the beginning some of us oppose and some of us support, this would not work. [...] These people are entrusted to us by our ancestors (Interview, May 2014).

Despite the tone of responsibility, Governor 2 was more forthcoming to accept the absence of long-term planning beyond immediate pragmatism.

There is an end to patience. As time passes, these Syrians will organize themselves. There can be conflicts of interests. There ought to be planning, problem-solving, regulating considering the long duration [of this crisis]. Integration is very important. The integration of our people is also very important. We need mutual cooperation.

As I have argued above, a process of 'discursive governance', which appeals to the collective memory of the Turkish state as a 'charitable' polity with close personal relations with the Syrian nation, dominates 'innovative' policy-making in the central and local administrations. At the same time, by putting an emphasis on 'how things have been 
and are' in Turkey and Turkish society, the interviewees are referring to a collective memory of Turkish generosity in the region. What affects inclusion then is historical and moral responsibility rather than a prevailing humanitarianism per se. To this extent, a more recent metaphor to qualify the role that Turks should play for Syrians in Turkey has been ensar. As a metaphor, ensar refers to the people of al-Madinah, who supported the Muslims that migrated there from Makkah and in essence points at a temporary situation (as the Muslims returned to Makkah when their forces recaptured the city from the pagans).

The politicians and various public actors are marking guidance and religious advocacy of Syrians in Turkey with this metaphor and, hence, seek to influence the public sphere discursively rather than initiating a rights-based relief and integration programme for all refugees. President Erdoğan has been a vocal advocate of this metaphor and introduced it while addressing Syrians in Gaziantep immediately after his election to office in 2014. After voicing his hopes that conditions would improve in Syria as soon as possible, so that the guests could return their homes, he reminded them that 'we in Turkey have been pleased and deservedly proud of hosting you here for nearly four years'. He continued 'we have one-and-a-half million of our brethren as guests [...] We have spent thus far more than four billion dollars, while Europe closed its doors on you [...] The despotic Assad will be accountable for this [...] As I am telling the West, the crisis in Syria cannot be solved with air bombardments, there is a need for deeper military engagement including troops' (Haber7, 2014). I consider the use of this metaphor essential to our understanding of how discursive governance operates in the public sphere, supported by noteworthy references to the generosity of the Turkish nation during this temporary situation.

I indicated in the previous section that discursive processes would enhance their resonance as they operate in conjunction with institutional mechanisms in political contexts. The institutionalization of temporary protection and selective humanitarianism operate in conjunction with references to collective memory of the nation to emphasize their responsibility to the Syrian refugees. However, those refugees who deserve help are also the ones framed as Turkey's 'relatives' and 'religious brothers'. This approach leaves out a large group of refugees seeking relief in Turkey. In order to depict what this discursive framework implies for other refugees, the next section presents a comparative picture of the status of other refugees in Turkey.

\section{Syrians and others: an elaboration on temporary protection}

Even if temporary-resident status is by law to be applied for all Syrian nationals, Turkey's involvement in the crisis alongside the Sunnite factions fighting against the Assad regime leads to non-Arab, non-Muslim, and non-Sunnite refugees' becoming suspicious of Turkey's intentions, refusing to register with the authorities and declining places in refugee camps. In a way, this nature of uptake also serves to resonate 'the charitable Turkish public helping their Sunnite religious brethren' discourse in the Turkish public sphere and justify AKP's Syrian policy. Although a systematic study is still lacking, in effect temporary-resident status seems to assist mostly those Syrians that are Sunnite and Arab to gain access rights and protection. Moreover, Turkey's prioritization of Syrian refugees, at least to guarantee their temporal residence, paves the way for the situation where other refugee issues drop off the agenda. Even without 
Syrians, Turkey hosts a sizeable refugee population composed of Afghans, Iranians and nationals of south-east Asian and African states.

Furthermore, since the beginning of the incursions of IS in the region, Turkey has become a destination for waves of Christian and Yazidi refugees from Iraq as well as Kurds from Kobanë in Syria. These populations put a particular pressure on the management of Turkey's selective humanitarianism. The situation of Iraqi nationals differs from Syrians and rather compares with the traditional refugee populations in Turkey categorized as non-eligible for asylum, given their countries of origin. While the situation of Syrian Kurds could be dealt with under the temporary-protection system, their ethnicity challenges the ideological tenets of the temporary-protection regime that AKP has been keen to develop for 'victims' of the Assad regime, that is, people of Arab/ Muslim/Sunnite origin. In order, this article proposes a comparative study of refugee populations to delineate the differentiation among them based on their national, ethnic and religious origins, which affects both the treatment that they receive and their willingness to approach Turkish authorities for assistance.

The Syrian crisis gained a new and more complex character following the incursions of IS, culminating in summer 2014, targeting non-Sunnite and particularly the ancient Christian and Yazidi populations in the region. Hence, starting with summer 2014, Turkey has faced a more complex mass movement of people toward its borders, who are not necessarily of an ethnic and religious character that the AKP establishment has so far felt itself at ease with. Although in some instances these people can have access to camps, media reports from the region show they feel themselves more secure in the hands of mostly Kurdish-led HDP (Peoples' Democracy Party) local governments in south-eastern Turkey as well as their communities. Thereby, the handling of nonSunnite, non-Arab and non-Syrian refugees has become a litmus test for Turkish refugee regime and humanitarian diplomacy. In order to understand the implications of selective humanitarianism, I will now examine the treatment that different refugees have experienced in Turkey.

Irrespective of the Syrian refugees, Turkey sees an increasing number of asylum applications from Afghan, Somali, Iraq, Russian and Iranian citizens, with the numbers reaching 200,000 by 2015 (UNHCR, 2015). According to the UNHCR 2014 report, issued before the humanitarian crisis caused by the IS incursions, Turkey has seen an unprecedented increase in the number of non-Syrian asylum applications over the past 24 months. In 2014, the UNHCR estimated an annual increase in the arrival rates of $40 \%$ for Iranians, $50 \%$ for Iraqis and $100 \%$ for Afghans. Based on these assumptions, the UNHCR expected that there would be over 100,000 people of concern in Turkey in 2014, not including Syrians (UNHCR, 2014) and adding to others that are already in the country. However, the 2015 Report shows that this expectation doubled with the increasing arrival of Iraqis. Furthermore, the number of Afghans has also increased drastically with arrivals through Iran.

As noted above, non-Europeans are eligible for temporary asylum in Turkey before they are resettled in third countries by the UNHCR. There is however a very long waiting list even to register with the UNHCR, let alone to wait for resettlement. While in Turkey, refugees live dispersed around the country in 'satellite towns' away from city centres, and they need to register with the police regularly. While they can send their children to school, they have ad hoc access to healthcare and no right to work. In 
protest about their situation, a group of Afghans started a hunger strike at the UNHCR office in Ankara in 2014 (Zaman, 2014). The reticence of the Turkish authorities to accept non-Europeans as asylum seekers, therefore, triggers their search for a better destination. Yet, the continuous Turkish geographical limitation also reflects the general public philosophy toward immigrants in Turkey. The Eurosphere Turkey report provided ample data on this factor (Küçük, 2010, p. 11). The Turkish public advocated differential treatment of immigrants depending on their ethnic background, favouring immigrants with co-ethnic backgrounds. One respondent stated that if one accepts everyone, like migrants coming from Bangladesh, Sri Lanka, India or China, that would bring chaos to Turkey...it is normal that the Turkish state makes its own decisions as to whom it accepts or rejects' (Küçük, 2010, p. 11). Küçük's finding draws a convincing link between the continuous geographical limitation in Turkey's asylum regime and the public philosophy behind it. The media reporting on the circumstances of migrants from Asian and African countries, and the abuses they go through to reach Europe, replenish an adverse image of immigrants, depicting them in such despair to assume abysmal work and living conditions (Eslen-Ziya \& Korkut, 2013; Fait, 2013). While temporary protection is introduced for Syrians, there is a continuous ignorance regarding other nationalities.

In the second half of 2014, refugees fleeing Iraq and Syria in the face of the incursions of the Islamic State further exacerbated the pressure on the Turkish immigration system. Their reception and conditions present a case to depict the difference between the protection that Syrians receive in comparison to the other refugees, though they are all in need of humanitarian assistance. The number of Iraqis have increased following the IS incursions with the arrival of Yazidis and Christians (BGST, 2015). It is difficult to obtain exact figures in terms of their numbers. Nurcan Baysal proposed that the number of Yazidi refugees in Turkey would be around 18,000 to 30,000 - mostly hosted by the local governments in the region as well as the Yazidi communities who are Turkish citizens. Similarly, the Armenians of Syria leaving their lands in the face of IS incursions have been hosted by the Armenian community in Vakuflıöy, the only Armenian village in Turkey. Turkish security forces issued them with a type of a foreign-national certificate with which they can have access to healthcare services for births and operations, but only in hospitals within the region unlike nation-wide access for Sunnite Syrians. However, if they are not Syrian nationals, they do not have access to temporary-residence status or the associated rights (BGST, 2015).

The Kurdish refugees from Kobanë, however, fostered the greatest challenge to the AKP discourse towards Syrian refugees. The IS incursions into the mostly Kurdishpopulated Kobanë starting on 15 September 2014 presented Turkey with a dilemma between security considerations and humanitarianism. As the Kurdish population from Kobanë has been under the jurisdiction of a Kurdish cantonal region sympathizing with the PKK (a Kurdish military group long listed as a terrorist organization by Turkey, the EU and the US), humanitarianism toward and collaboration with Kurdish forces against IS would have meant making concessions to Turkey's decades-long foe - the Kurdish militants. Moreover, keeping an open-door policy toward Kobanë Kurds - a group that is characteristically at odds with the brotherhood narrative that Turkish officials constructed toward Sunnite and Arab Syrians - would have had political costs for the AKP. The 'guest' narrative that the AKP has introduced to frame the 'temporary 
protection' policy was developed for victims of 'Assad despotism' and could not simply be applied to victims of the IS terror in the region.

At the height of the battle between the IS forces and the Kurdish forces for the control of Kobanë, the then Deputy Prime Minister Bülent Arınç, in an interview on a local TV station in Bursa, declared that 'we always criticized the Syrian regime in the face of its cruelty against its own population, but we also embraced those people who have run away from there to save their lives. Now, if a similar stream of people start from North of Syria, and this brings Kurds to Turkey, this may end up as a material and moral destruction for Turkey'. Pragmatically, Arınç suggested that Turkey should keep these people 'where they are'. Yet, according to Arınç, and given the Turkish past of charity and generosity, 'we are obliged to do this [protect Kurds where they are]. We are a Turkish nation; we have public spirit. If someone asks for help from us [...] we need to open our hearts [...]. The Turkish nation did this in every period in history' (Radikal, 2014).

The reluctance by the AKP government to keep Turkey's borders open for Syrian Kurds as well as its initial intolerance for Kurdish fighters from Iraq and Turkey to join in the defence of Kobanë against the IS instigated clashes between the Turkish security forces and the Kurds in October 2014. Riots broke out in the border regions, leaving at least 35 people dead (Salih \& Stein, 2015). At the height of the Kobanë crisis, Turkey eventually accepted a few thousand refugees of Kurdish origin, but most of them went back to Kobanë as soon as the fighting ended. Many of them refused to take places at separate camps that AFAD had organised, given their lack of confidence in Turkish authorities in the face of allegations that they have relationship with IS. However, the difference between Kobanë Kurds and the rest of the Syrian citizens became most acute in a note from AFAD dated 11 December 2014, which stated that around 230,000 refugees from Kobanë as well as Sengal (the region where Yazidis are left in Iraq) should not have access to temporary-protection status and, hence, should not have similar protection to other Syrians such as healthcare assistance (T24, 2014). This is a clear example of humanitarianism not being extended to those with different backgrounds and an indication of how refugees differ in terms of the treatment that they have received.

The needs of non-Muslim and/or non-Syrian refugees from Iraq are comparable to those of Syrian refugees. While they may not be running to escape from the 'despotism of the Assad regime', the narrative with which Erdoğan has been very keen to qualify the Syrian refugees, they are seeking refuge in Turkey due to the extensive repercussions of civil war in Syria. As they do not come from Syria, however, Turkish authorities do not extend temporary protection to them. Hence, the geographical limitation clause applies to their cases, making them face even more perilous circumstances than the Syrians. Devoid of refugee protection, similar to other asylum seekers in Turkey, such as Iranians and Afghans, the Iraqis are also forced to use Turkey for transit. In summer 2015, the Yazidis started to voice that European nations should accept them en masse.

For Yazidis, the Kurdish HDP-led local governments in south-eastern Turkey launched a protection initiative, leading the Turkish media to report that Yazidis have links with the PKK and had demanded autonomy for their homeland in Sengal (Sincar) province in Iraq (Radikal, 2015). While AFAD also allocated camp space for Yazidis to host around 17,000 people, according to Baysal, Yazidis do not go to these camps as 
they distrust the Turkish authorities on the premise that they have relations with the IS. Another issue is the lack of a collaborative relationship between the Kurdish local governments and AFAD in order to run these camps together. Overall, Baysal reports that despite Prime Minister Davutoğlu's earlier statements that Turkey caters for 200,000 people from Kobanë, there were only around 6,000 Kurds from Kobanë and 2,500 Yazidis in camps, while around 220,000 people stayed outside the camps (BGST, 2015) as a further indication of distrust of Turkey.

While their numbers are relatively smaller, Assyrian refugees face similar issues. Rather than entering the camps, it is also common for the Assyrian refugees (even those who are Syrian nationals) to be hosted by their own communities in Turkey. According to the Assyrian International News Agency, when AFAD organized a Christian section at refugee camps, only a few families moved in, and the rest preferred to stay with Turkish Assyrian communities either in south-eastern Turkey or in Istanbul. According to the President of the Meryem Ana Church Foundation in Istanbul, Sait Susin, the Assyrian refugees are mostly in transit. They need a place to stay until they move on to another country (AINA News, 2014; AINA News, 2015). However, in 2015 news indicated that the Assyrians suffered from Turkey's decision to partially close the bordercrossing with Syria, situated next to some Assyrian settlements amidst the IS assaults in the area. According to the Assyrian Archbishop, while 200 families were trying to escape to Turkey, Turkey closed the border in the area. As a result, the Assyrians fell hostage to IS forces attacking the area (AINA News, 2015).

Furthermore, there is also the case of stateless people from Syria. While they also have rights to gain temporary protection, their position is more complex than it appears. As these people are mostly of Palestinian and Kurdish origin, and hence lack Syrian citizenship, they would need visas to enter Turkey or otherwise face being in Turkey illegally. While maintaining an open-door policy for Syrian nationals, the Turkish government made the visa regime for Palestinians much stricter. Milli Gazete, a conservative Islamist daily associated this with the fear among AKP circles of a mass movement of people from Palestine to Turkey (T24, 2015c). Turkey also closed its diplomatic representations in Syria. According to Şenay Özden (BGST, 2015), the Turkish Consulate in Beirut stopped issuing visas two years ago, making it impossible for Palestinians even to apply for a visa.

One final note regards the most recent stream of refugees of Turkmen origin from Syria that seek protection in Turkey in the face of increasing clashes between IS and Kurdish forces in Syria in June 2015. In this instance, Turkey chose to refuse entry to Turkmens, indicating that their tragedy is due to ethnic cleansing in the region by the Kurdish forces to establish a Kurdish zone around Turkey. Hence, similar to the case of the Kurds from Kobanë, but different from the Syrian Arabs, the AKP government stated that Turkmens should remain in Syria in a safety zone (Zaman, 2015). The idea behind this move seems to be to keep people of Turkish descent in their original settlements in Syria rather than having them all immigrate to Turkey.

This section has presented a comparative picture regarding how the Arab/Muslim/ Sunnite Syrian refugee population differs from the rest in terms of the relief and protection they receive while in Turkey. It indicates how the 'guest' narrative functions, while an institutionalization of a rights-based refugee policy is absent. In fact, the varying treatment that Syrians receive from the Turkish authorities based on their religion 
and ethnicity makes them accept an ethnic identity beyond their Syrian identity while seeking refuge in Turkey (BGST, 2015). It may then be that Turkey's insistence on selective humanitarianism is forcing the Syrians to select more primordial associations rather than simply being Syrian.

\section{Conclusion}

The recent Syrian refugee crisis showed that the AKP government of Turkey maintains a pragmatic and selective approach in the application of refugee rights and protection. AKP promotes a feeling of affinity with the Sunnite Muslim Arab Syrian refugees in comparison to other refugee groups from Syria and Iraq. Hence, the government can introduce and maintain a temporary-protection policy for this particular section of Syrian refugees more effectively than for the others. Essentially, when examining the ideological tenets of selective opening, this article compared Arab/Muslim/Sunnite Syrians with the rest of Turkey's refugees in terms of the protection that they receive in Turkey. It also reflected on the status of Yazidis from Iraq as refugees in the face of the repercussions of the Syrian civil war, but not qualified for temporary protection.

What is particularly crucial for the Turkish government's position toward the Syrian refugees is the lack of integration policies and programmes. As the interviews at three different levels of Turkish public administration have shown, the officials follow a particular discursive framework appealing to the collective memory of the Turkish state and society as a charitable polity and a traditionally generous society. This particular discursive construction seeks to culminate in public support for the government's position vis-à-vis the Syrian refugees, but falls short of institutionalizing comprehensive humanitarianism and integration policies to respond to the needs of refugees. While this discursive framework conceives certain sections of refugees as guests and temporary, it maintains the rejection of non-Arab, non-Muslim, non-Sunnite refugees. Turkish humanitarian diplomacy toward Syrian refugees suggests that the only victims in the Syrian conflict are the Arab/Muslim/Sunnite populations that suffer from Assad's despotism. Hence, their suffering necessitates that Turkey temporally hosts and assists them. Overall, this article has debated the Syrian refugee crisis as a case study to assess how far Turkey's immigration policy can maintain pragmatic solutions but avoid drastic changes in policy and public philosophy dealing with foreigners.

However, a series of attacks on Syrian refugees in different Turkish cities since the summer of 2014 showed that the Turkish public is reactive to incoming Syrians, despite the religious affinity emphasised by AKP politicians and the media. This may be an indication of ethnic differences between Syrians and Turks, or it may be simply due to an expression of welfare or commercial chauvinism by the native population. While it is not the primary aim of this article, hence, it also illustrates that the government's selective reception of refugees may not pacify the public reaction to foreigners in Turkey.

\section{Endnotes}

${ }^{1}$ There is confusion regarding who can work in Turkey legally. While the Ministry of Labor claims that those who register with the police, regardless of how they entered Turkey, can work legally, AFAD maintains that only those who enter Turkey with a valid passport can receive a 12-month temporary permit and hence legal access to work. The Turkish media frequently mention conflicts that the informal Syrian 
workforce generates in the labor market. This may be due either to Syrians' unwillingness to register with the police or to their illegal entry into Turkey without valid passports.

\section{Competing interests}

The author declares no competing interests.

\section{Authors' information}

Umut Korkut is a Reader in Politics at Glasgow School for Business and Society Glasgow Caledonian University.

\section{Acknowledgments}

I am indebted to the anonymous referees for their insightful comments. This work was supported by The Carnegie Trust for the University of Scotland. I also wish to thank Slavic-Eurasian Research Center, Hokkaido University for offering me the 2015/2016 foreign visiting fellowship that brought this article to conclusion.

Received: 21 June 2015 Accepted: 24 December 2015

Published online: 02 March 2016

\section{References}

AFAD. (2014). AFAD Basın Açıklaması [Press Release of AFAD]. https://www.afad.gov.tr/tr/HaberDetay. aspx?ID=12\&lcerikID=3024. Accessed 7 July 2015

AKP. (2011). Suriye meselesi bizim iç meselemizdir [Syria is our internal affair]. https://www.akparti.org.tr/site/haberler/ suriye-meselesi-bizim-ic-meselemizdir/11521\#1. Accessed 2 December 2015

AINA News. (2014). Syria's Assyrian Christians Find Refuge With Turkish Neighbours. http://www.aina.org/news/ 20140127171559.htm. Accessed 20 May 2015

AINA News. (2015). As Assyrian Hostages in Syria Spike, Turkish Border Closed to Refugees. http://aina.org/news/ 20150227141914.htm. Accessed 20 May 2015

Aras, B. (2004). Turkey and the Greater Middle East. Istanbul: Tasam Publications

Asylum and Migration Legislation (2005). Ankara.

Baydar Aydıngün A. (1998-1999). A Deported Nationality: The Ahıska Turks. Perceptions, III, (4). http://sam.gov.tr/wpcontent/uploads/2012/02/AyesegulBaydarAydingun.pdf. Accessed 16 December 2015

BBC. (2014). Turkey protest in Istanbul over Syrian refugees, BBC News. http://www.bbc.co.uk/news/world-europe28926956. Accessed 26 May 2015

BGST. (2015). Türkiye Artık Göçmenler Ülkesi [Already Turkey is an migrant destination]. http://bgst.org/ulke-gundem/ turkiye-artik-gocmenler-ulkesi-panel-metni. Accessed 20 May 2015

Bhatia, V \& Orsini, M. (2014). Narrating Sustainability in Canadian Health Policy Discourse. Social Policy and Administration. doi:10.1111/spol.12103

Bruner, J. (1996). The Culture of Education. Cambridge, Mass: Harvard University Press.

Castles, S. (2000). International Migration at the beginning of the twenty-first century: global trends and issues. International Social Science Journal, 52(165), 269-281.

Cox, R. H., \& Béland, D. (2013). Valence, Policy Ideas, and the Rise of Sustainability. Governance, 26(2), 307-328.

Davutoğlu, A. (2013). Turkey's humanitarian diplomacy: objectives, challenges and prospects. Nationalities Papers: The Journal of Nationalism and Ethnicity, 41(6), 865-870.

Eslen-Ziya, H., \& Korkut, U. (2013). Domestic work, gender and migration in Turkey: Legal framework enabling social reality. In U. Korkut, G. Bucken-Knapp, A. McGarry, J. Hinnfors, \& H. Drake (Eds.), The Politics and Discourses of Migration in Europe (pp. 37-52). New York: Palgrave/Europe in Transition: The NYU European Studies Series.

Fairhurst, G. T. (2009). Considering context in discursive leadership research. Human Relations, 62(11), 1607-1633.

Fait, N. (2013). African migrations toward Turkey: Beyond the stepping stone. Ankara Üniversitesi SBF Dergisi, 68(1), 21-38.

Fischer, F., \& Gottweis, H. (2013). The argumentative turn in public policy revisited: twenty years later. Critical Policy Studies, 7(4), 425-433.

Gamson, W. (1992). Talking Politics. Cambridge: Cambridge University Press.

Göç Idaresi Genel Müdürlüğü. (n.d.). Law on Foreigners and International Protection. http://www.goc.gov.tr/icerik6/ laws913980981icerik. Accessed 20 May 2015

Gürsel, K. (2012). Milletin meselesi nasıl milli mesele olur? [How does public affair become national affair?]. Milliyet, 28 June.

Haber7. (2014). Cumhurbaşkanı Erdoğan: Bizler Ensar sizler muhacir TThe President Erdoğan: We are Ensar you are muhacir]. http://www.haber7.com/ic-politika/haber/1208342-cumhurbaskani-erdogan-bizler-ensar-sizler-muhacir. Accessed 7 July 2015

Han, A. K. (2013). Paradise Lost: A Neoclassical Realist Analysis of Turkish Foreign Policy and the Case of Turkish-Syrian Relations. In R. Hinnebusch \& Ö. Tür (Eds.), Turkey-Syria Relations. Between Enmity and Amity (pp. 55-70). Aldershot: Ashgate.

Hinnebusch, R., \& Tür, Ö. (Eds.). (2013). Turkey-Syria Relations. Between Enmity and Amity. Aldershot: Ashgate.

Ilgıt, A, \& Davis, R. (2013). The Many Roles of Turkey in the Syrian Crisis. Middle East Research and Information Project, http://ns2.merip.org/mero/mero012813. Accessed 16 December 2015

Iszatt-White, M. (2011). Methodological crises and contextual solutions: An ethnomethodologically informed approach to understanding relationship. Leadership, 7(2), 119-135.

Korkut, U. (2014). The migration myth in the absence of immigrants: How does the conservative right in Hungary and Turkey grapple with immigration? Comparative European Politics, 12, 620-636.

Korkut, U., Mahendran, K., Bucken-Knapp, G., \& Cox, R. H. (Eds.). (2015). Discursive Governance in Politics, Policy, and the Public Sphere. New York: Palgrave Macmillan. 
Küçük, B. (2010). Diversity and the European Public Sphere: The Case of Turkey. Eurosphere Country Report No. 4, http://eurospheres.org/files/2010/06/Turkey.pdf. Accessed 16 December 2015

Lakoff, G., \& Johnson, M. (1980). Metaphors We Live By. Chicago, IL.: University of Chicago Press.

Milliyet. (2014). İitelli'de tehlikeli gerginlik! [Friction at Ikitelli]. http://www.milliyet.com.tr/ikitelli-de-tehlikeli-gerginlikgundem-1930400. Accessed 26 May 2015

Nimmo, D., \& Combs, J. (1980). Myths and Myth Makers in America. Englewood Cliffs, NJ: Prentice Hall. Subliminal Politics.

Öniş, Z. (2014). Turkey and the Arab Revolutions: Boundaries of Regional Power Influence in a Turbulent Middle East. Mediterranean Politics. doi:10.1080/13629395.2013.868392

Özden, S. (2013). Syrian Refugees in Turkey. European University Institute Migration Policy Centre. http://www. migrationpolicycentre.eu/docs/MPC-RR-2013-05.pdf. Accessed 16 December 2015

Patterson, M., \& Monroe, K. R. (1998). Narrative in political science. Annual Review of Political Science, 1, 315-331.

Radikal. (2014). Arınç'tan göç dalgası uyarısı [Arınç warns about waves of migration]. http://www.radikal.com.tr/politika/ arinctan_goc_dalgasi_uyarisi-1213822. Accessed 19 May 2015

Radikal. (2015). Asker Ezidilerin kampına girdi [The soldiers have entered Yazidi camps]. http://www.radikal.com.tr/ turkiye/asker_ezidilerin_kampina_girdi-1266515. Accessed 20 May 2015

Salih, C. \& Stein, A. (2015). How Turkey misread Kurds. http://www.aljazeera.com/indepth/opinion/2015/01/how-turkeymisread-kurds-201511910421859659.html. Accessed 2 June 2015

Searle, J. R. (2010). Making the Social World - The Structure of Human Civilization. Oxford: Oxford University Press.

Shanahan, E. A., McBeth, M. K., \& Hathaway, P. L. (2011). Narrative Policy Framework: The Influence of Media Policy Narratives on Public Opinion. Politics \& Policy, 39(3), 373-400.

T24. (2014) Şengal'den gelenler sağlık hizmetinden yararlanamayacak mı? WWill Sengal refugees have an access to healthcare?]. http://t24.com.tr/haber/sengalden-gelenler-saglik-hizmetinden-yararlanamayacak-mi,281466. Accessed 8 July 2015

T24. (2015a) Suriye'den Türkiye'ye gelen işçiler hastalığa yakalanıyor [The workers form Syria caught illnesses]. http://t24. com.tr/haber/suriyeden-turkiyeye-gelen-isciler-hastaliga-yakalaniyor,301703. Accessed 7 July 2015

T24. (2015b) Bodrum'da esnaf şikayet etti, 40 Suriyeli Türkmen Aydın'a sürüldü! [The shop owners in Bodrum complained, 40 Turkomans from Syria were taken to Aydin]. http://t24.com.tr/haber/bodrumda-esnaf-sikayet-etti40-suriyeli-turkmen-aydina-suruldu,297784. Accessed 26 May 2015

T24. (2015c) Milli Gazete: Türkiye, Filistinlilere 'one minute' çekiyor, vize vermiyor [Milli Gazete: Turkey rejects visa applications from Palestians]. http://t24.com.tr/haber/milli-gazete-turkiye-filistinlilere-one-munute-cekiyor-vizevermiyor,284852. Accessed 20 May 2015

Teitelbaum, M. S. (1984). Immigration, refugees, and foreign policy. International Organization, 38(3), 429-450.

UNHCR. (2013). Global Report Turkey, http://www.unhcr.org/539809ffo.html. Accessed 5 January 2016

UNHCR. (2014). Syria Regional Response Plan - Turkey.

UNCHR. (2015). UNHCR Country Operations Profile - Turkey.

UNCHR. (n.d.). Frequently Asked Questions Syrian Refugees in Turkey. http://www.unhcr.org.tr/uploads/root/faqenglish. pdf. Accessed 2 June 2015

Zaman. (2014). Türkiye'deki Afgan Mülteciler [Afghan migrants in Turkey]. http://www.zaman.com.tr/yorum_turkiyedekiafgan-multeciler_2225119.html. Accessed 7 July 2015

Zaman. (2015). Suriyeli Türkmenler, sınırı mayınlı bölgelerden geçmeye zorlanıyor. http://www.zaman.com.tr/dunya_ suriyeli-turkmenler-siniri-mayinli-bolgelerden-gecmeye-zorlaniyor_2298541.html. Accessed 8 July 2015

Zolberg, A. (1989). The Next Waves: Migration Theory for a Changing World. The International Migration Review, 23(3), 403-450.

Zolberg, A., Suhrke, A., \& Aguayo, S. (1986). International Factors in the Formation of Refugee Movements. The International Migration Review, 20(2), 151-169.

\section{Submit your manuscript to a SpringerOpen ${ }^{\circ}$ journal and benefit from:}

- Convenient online submission

- Rigorous peer review

- Immediate publication on acceptance

- Open access: articles freely available online

- High visibility within the field

- Retaining the copyright to your article

Submit your next manuscript at $>$ springeropen.com 